\title{
Malkom Khan's Thoughts on Political Modernization from Bottom in Iran
}

\author{
Kamyab Shahriari (Corresponding Author) \\ Department of Politics and Government, Faculty of Human Ecology, University Putra \\ Malaysia (UPM) \\ Serdang, Selangor, Malaysia \\ E-mail: shahriarikamyab@gmail.com
}

Ku Hasnita Ku Samsu

Department of Politics and Government, Faculty of Human Ecology, University Putra Malaysia (UPM)

Serdang, Selangor, Malaysia

E-mail: hasnita@upm.edu.my

Received: August 18, 2014 Accepted: September 1, 2014 Published: December 23, 2015

doi:10.5296/ijch.v2i2.6148 URL: http://dx.doi.org/10.5296/ijch.v2i2.6148

\begin{abstract}
Malkom Khan in the second period of his political activity either as activist or as political thinker chose a different approach to political modernization. In this period, instead of addressing the monarch and government to gain their support for modernization, he addressed the people and adopted the approach of political modernization from bottom. In this period Malkom Khan proposed the idea of parliamentary constitutional monarchy and introduced this kind of government as the most proper government for Iran and in this regard for the first time he proposed the formation of the national consultative assembly, with its representatives elected not by the monarch but by the people. In line with parliamentary constitutional monarchy Malkom Khan proposed new and modern structures and institutions in order to achieve the political modernization program. Research result shows that his political thoughts faced a major shift. Unlike the first period of his thoughts during which his idea of political modernization was based on state building, in this period it is based on nation building and in order to prevent possible opposition from the clergy and conservative and
\end{abstract}


religious segment of the populace to his thoughts and also in order to attract the support of the progressive class of clergymen with his political modernization thoughts he advocated a reconciliation of modern political thoughts with Islamic beliefs and teachings.

Keywords: Iran, Political modernization, Malkom Khan, Constitution

\section{Introduction}

After coming to a stalemate over reform by king and officials and Malkom Khan's own despair of political modernization from above, three events led him to abandon political modernization from above and adopt political modernization from bottom: the failure of Sepahsalar's reform program, the Tobacco Movement and more importantly, the Lottery Affair and Malkom Khan's subsequent dismissal which made him turn against the government by publishing the Ghanoon newspaper that opposed Nasser al din shah publicly. In this newspaper, Malkom Khan, for the first time, proposed parliamentary constitutional monarchy instead of law-based absolute monarchy and regarded this type of government as the most proper type of government for Iran. This was in order to limit the power of the monarch by proposing the idea of separation of power. In fact, in this period, his political direction had shifted and during this period he considered the importance of religion and religious forces and their role in traditional and religious countries like Iran and attempted to use these factors to underline and advance his political modernization program.

This article attempts to examine Malkom Khan's political thoughts to uncover his ideas on political modernization in the second period of his political thought,

\section{Malkom khan and Parliamentary Constitutional Government}

As has been mentioned in a previous chapter, Malkom Khan introduced law- based absolute monarchy as an ideal type of government for Iran in the course of modernization from above. However, after thirty years, he proposed a parliamentary constitutional monarchy instead as the ideal type of government in Iran. Malkom Khan stated that establishment of law and law-based government was the pillar of the political modernization program right from the first issue of the Ghanoon newspaper. According to him, even the most inferior rules are better than lawlessness.

"We don't say that we want the laws of Paris, Russia or India. The principles of good laws are the same everywhere and principles of the best laws are from God. But we have been battered so much from lack of performance of these rules and now we need a law, no matter how rudimentary it is, because the most inferior laws are better than lack of law" (Malkom Khan, 1976e).

He represents Iranian society and its condition realistically, providing a dynamic and precise analysis. This analysis shows that although he spent the main period of his political activity outside of Iran, he had an accurate view by means of various relationships at all levels and also due to his innate political intelligence. He did criticize the despotic government in the previous period, but in this new period, from the very first issue of Ghanoon, his criticisms were much more forceful. He wrote in the first issue of Ghanoon that: "There are no people 
in Iran who know what is fault and what is service" (Malkom Khan, 1976e). He wrote in one of his treatise titled osule mazhabe divanian that in non-Muslim governments, the duty of the army is to protect the rights of the nation, but in Iran, the mission is to flee from the enemy on all fronts and killing their own compatriots without question to display their perverted sense of power (Asil, 2002b).

\section{National Consultative Assembly}

As mentioned in a previous chapter, Malkom Khan proposed two different parliaments which were majlise tanzimat and majlise vozara, in the course of promoting his idea of law based absolute monarchy (hokoomate motlaghey-e montazem) and modernization from above, but in the second period of his political thought, he shifted his idea and proposed parliamentary constitutional monarchy for Iran in the course of modernization from bottom and for this purpose, he introduced the majlise shoraye dolati or governmental consultative assembly as the legislature.

He defined law-making and the legal system in the form of its previous plans and believed that the sequence of rule in Iran should be the work of the majlise shoraye dolat (governmental consultative Assembly) which could competently properly organize the running of the Iran government. Malkom Khan proposed that the representatives of the Majlis should comprise prominent scientists, well-known citizens, prominent members of the clergy and even capable youths from all parts of the country.

According to Malkom Khan, the rule of law is the gathering of power of the people in order to ensure the people's rights (Zibakalam, 2006). In this context, the "king's will cease to exist and should be replaced by laws based on the principles of justice. The principles of justice are divinely inspired and mouthed by wise men and sages. Law is the language and power of justice, but this power will not be able to be manifested unless the people are united in their intense want of this (Malkom Khan, 1976d). Malkom Khan in Ghanoon began with the idea of a "government consultative assembly" which evolved into the national consultative assembly (majlise shoraye melli). He was the first Iranian thinker who advocated the necessity of establishing a national consultative assembly in the history of Iranian political thought. In the sixth issue of the Ghanoon newspaper, while answering the question of "Where would the law come from and how should it be implemented" he pointed out that:

"We should gather at least one hundred great clergymen and great people, well-known scientists of Iran in the capital of the nation, in a national consultative assembly and give them complete power and mission to determine those rules and principles required for Iran. Secondly, in accordance with a documented contract, they should be careful in implementing the law, for without this last condition, that is, the presence of a national assembly which constantly oversees the implementation of the law, the best laws of the world would be ineffective and useless" (Malkom Khan, 1976c).

Then, Malkom Khan outlined his modernization plan to establish a constitutional government more clearly than before. The Majlis or national consultative assembly, with at least 70 representatives drawn from the clergy, and other prominent figures from various segments of 
Iranian society, would be committed law makers with executive powers. While the selection and appointment of ministers remains the prerogative of the king, the assembly of ministers must be accountable to the national consultative assembly (Malkom Khan, 1976q). Malkom Khan believed that all ministers should be responsible to parliament, meaning that parliament had the right to dispense justice. Any minister involved in misdeeds in governance and proven guilty must be punished according to the law and also matters of income and expenditure of the government should be with the permission of parliament (Malkom Khan, 1976q). Although here Malkom Khan placed the Majlise or national consultative assembly in a higher position than the assembly of ministers, in this way he managed to place the king's power within the framework of law, and also emphasized the supervision of people holding political power. However he stopped short of suggesting that the selection of parliamentary representatives should be by the people.

However, he did stress that that the appointment and dismissal of parliamentary representatives should be based on law. Although Malkom Khan knew that his concept of the legislative assembly was incompatible with traditional and conservative Islamic thought, nevertheless he tried to secure the most political power for representatives of the national consultative assembly. He wrote: "The representatives would enjoy freedom of speech within the assembly, within the laws that you yourselves created. it is clear that every national plan should be based on the tenets of Islam and Adamiyyat or the principles of humanity" (Malkom Khan, 1976p). In the $25^{\text {th }}$ issue of the Ghanoon newspaper, Malkom Khan encouraged the people to select representatives of the national consultative assembly. $\mathrm{He}$ believed that people must select their representatives to attend the national consultative assembly through participation in elections. Indeed, Malkom Khan's project was unprecedented in the history of Iran. He was suggesting that the representatives be elected by the people, not appointed directly by the Shah, for in this way the people were personally responsible for their own destiny (Haghani, 2002).

In fact, Malkom Khan tried to develop a participant political culture among the people of Iran. Actually, by presenting this idea, Malkom Khan was trying to limit the absolute power of the king, by advocating a parliamentary constitutional monarchy. However, he had to try and force clergymen to support his political modernization program since they would probably be against it. Malkom was also worried about the possible reaction and opposition of the clergy and in order to justify his proposal to the national legislative assembly for such a parliamentary constitutional monarchy; he shrewdly implied that it was based on quotations of the Prophet and the Shiite Imams.

It took so long to realize where the idea of (Parliament) came from. Some say it belonged to the Prophets of God. Some say it belonged to Imam Ali, But the prevailing opinion is that it belongs to Adam and since then has been entrusted with the mystics and saints (Raoofi, 2007, p. 32).

As has been mentioned in the previous chapter, in the first round of his activities, Malkom Khan proposed the reform council to regularize the government whose members were chosen by the monarch and not by the people and its implementation depended entirely on the will of 
the monarch. But at this stage, he proposed the Majlis shoraye melli or national consultative assembly, whose representatives were elected by the people, as his main political modernization program and as the axis of the program. This shows two distinct approaches of Malkom Khan regarding political modernization. The first one was political modernization from above that led to the creation of a strong central government and the second one was political modernization from the bottom, the aim of which was to establish a parliamentary constitutional monarchy.

\section{Separation of Powers}

Malkom Khan spoke for the first time of the necessity of three powers in the structure of government in order to limit the power of the king in the course of establishing a parliamentary constitutional monarchy. According to him, it has been indisputably proven that for the rule of law to prevail in any land, there has to be a harmonious and balanced working of three separate powers of state. The three were: firstly the power of enacting laws; secondly power to implement laws, and thirdly: power to oversee the implementation of law the source of all faults of the nation was that there was no evidence of the proper implementation of the law in the country (Malkom Khan, 1976b). Malkom Khan wrote about the necessity for separating the three powers, without speaking about the quality of their performance, their equality and distribution of powers in society. He knew the problem of institutional establishment for surveillance of law performance and when questioned, responded quickly, though not very clearly about the quality of performance. He introduced the nation as the source of power for surveillance of law and stated that it was "the same as in the early years of the emergence of Islam" (Jamshidi, 1999). In the first round of his activities Malkom Khan, followed the reform of authority and his goal was to establish a law based absolute monarchy, putting the separation of the three forces within a regular totalitarian regime

\section{Creating the League of Humanity (Majam e Adamiyyat) as a Party}

By publishing the Ghanoon newspaper (law newspaper) Malkom Khan was determined to change the political situation, which was his main goal, and formed an organization named majma-e-adamiyyat (League of Humanity). Hence, he was aware that such a change needed a political organization. Each organizational core was called jame (a branch) and generally it included one authority named Amin (trustee) or director of branch. Each branch (jame) contained a minimum of 12 and a maximum of 240 members. The jame should have a monthly general meeting, with additional weekly meetings for more active members, and all gatherings were, if possible, to take place in a mosque (Algar, 1973, pp. 231-232). The League of Humanity was reorganized by Malkom Khan as a true organization only after the publication of the Ghanoon newspaper and during the course of modernization from bottom. He introduced an ideology named "Marame Adamiyyat" (The principles of humanity) for this organization. The origin of this ideology was European humanism and especially that of Auguste Comte's humanism thoughts.

Malkom Khan called his ideology "humanity" from the fourth issue of the Ghanoon newspaper and described a human as a person who is enthusiastic, a seeker of justice, 
knowledge and development, supporter of the oppressed and benevolent towards people (Malkom Khan, 1976m). It is significant to note that from this point, Malkom no longer supports the government but supports the people instead. This main goal of establishing the League of Humanity was to gain knowledge, establish law, to revive Iran and world development. Accomplishing these goals did not relate too closely with government officials, but as far as the League of Humanity was concerned, the situation had to change. Their instrument for this hope was cooperation and unity (Malkom Khan, 1976a). Toward the achievement of these goals, Malkom Khan organized the corps of the league of Humanity in Iran and even outside Iran. In replying to the question "What is the meaning of League of Humanity (majma e adamiyyat)?" he pointed out that the League of Humanity meant the community of those men united in a special gathering in order to protect their rights. To him, the League of Humanity was the school of the principles of humanity.

In Malkom Khan's previous period of activity, Faramoosh Khaneh was an intellectual gathering and assembly which was founded to train some staff to work in government bureaucracy with the aim of advancing the program of reforms from the top. But at this period, Malkom Khan founded the League of Humanity that was structured very much like a political party to attract and train elements from different classes of people to participate in the political struggle. From this viewpoint, the League of Humanity was a suitable organization for the political modernization program from bottom. Also, in this period, Malkom Khan wrote some treatises with the aim of promoting marame adamiyyat (principles of humanity). The principles of humanity is a treatise which deals more with the subject of encouraging people, especially progressive clergymen to be members of the League of Humanity. it also deals with the method of organizing the league. Thus, Malkom Khan published two treatises on "Hojjat and "Meftah" in the Ghanoon newspaper. He starts osoole Adamiyyat (Principles of Humanity) with this introduction:

"Praise the human who is looking for knowledge and is demanding humanity. The meaning and aim of existence is nothing except knowledge. The meaning and purpose of humanity is nothing except adamiyyat (humanity). Stand up, you Ignorant one! Stand up. Read this treatise (Principles of Humanity) again and again. Know that you won't be saved except by knowledge and you won't reach knowledge and freedom except by osoole adamiyyat" (Principles of Humanity) (Asil, 2002f, p. 326). Malkom Khan puts insan in the center of his osoole adamiyyat (Principles of Humanity) and emphasizes that whenever a man promotes his degree of insaniyyat from his previous position to a higher degree, he will enter Adamiyyat (humanity). Malkom Khan distinguishes between two concepts of insaniyyat and adamiyyat. The word Adam, moreover means more than simply a member of the human race, but rather as a being descended from Adam, the first man and the first prophet ennobled by God and endowed with spiritual qualities, which are a microcosmic reflection of divine attributes. Adam denotes a higher state than insan, which refers to man only as a member of a species. The term adam shodan has the sense of becoming a true human being or one capable of mystically realizing one's innate stature as a theomorphic creature (Algar, 1973, p. 229).

It had been previously mentioned that in the Faramoosh Khaneh episode, Malkom sought to invoke certain Sufi themes and to present a lodge as a place of spiritual striving and 
advancement, and now, with this successor organization, similar, but implicit attempts were evident in the very title of the organization itself. In the treatise osoole adamiyyat (Principles of Humanity) Malkom Khan defined the essence of humanity as progress, and the primary duty of the members of the league as striving toward spheres peculiar to the human race. In keeping with his determination to clothe a material reformation in the garb of religion, it was necessary to clothe the Western nature of this progress ideology in the guise of the ideology of the league, which was made out as being derived from the teachings of the prophets and mystics. Humanity, he declared, was a combination of religion and reason. Its establishment upon earth had been the highest goal of all the prophets. If this complete correspondence between humanity and the message of the prophets was not immediately apparent. It was because of the esoteric nature of the doctrine that had been transmitted. Humanity was held to originate either from Adam or from Ali who formed the fountainheads of the esoteric tradition. From that time onward it has always been entrusted to the saints and trustees of God (aulia va ausia).

In Ghanoon, by considering the Islamic beliefs of people, Malkom says that: "God has commissioned each human being to promote himself from being just a human to a position of humanity" (Malkom Khan, 1976n). And so, the main basis of his League of Humanity is human orientation and progress. Malkom Khan enumerated the seven duties of humanity as: first, avoiding performance of harmful action; second, performing virtuous deeds; third, removing oppression; Fourth, unity fifth, seeking of knowledge; Sixth, promoting humanity, and seventh, preserving order and regularity (Malkom Khan, 1976n). Malkom Khan also invited his readers to join the League of Humanity. He declared: "In our unity circle, you won't find any word or act which is not according to the principles of God's religion and detrimental to nation development" (Malkom Khan, 19761). It is here that he named the League of Humanity as hizbollah (The Party of God).

Then Malkom Khan emphasized the point that God had determined human happiness based on his effort. Then to create credibility among his readers towards this belief, he criticized Iranian social behavior and declared that the way to achieve happiness was through unity (ettefagh), "People of this country who were ignorant of this condition of happiness, have asked for all worldly developments from God and miracles from heaven when they should instead be asking for these from the efforts of humans themselves. Unaware of the advantages of a united nation and in their ignorance, blood has been shed and possessions have been lost in their desire to improve their lot. Through their irrelevant actions people have gotten into trouble instead of using the power of communion and the strength of unity in order to win"(Asil, 2002c).

Malkom Khan wrote again about organizing the League of Humanity. He complained that people were only concerned about seeking the human "Adam", and he set about gathering his followers and organizing the association, and encouraged their sense of willingness to accept responsibility and cooperation for the purpose of exaltation of humanity (Asil, 2002d). The "Adamiyyat" members, in Malkom Khan's opinion, had to subscribe to the custom of support which was of three types: rational support, financial support, and spiritual support. Malkom Khan called Majaame Adamiyyat the system of national unity. He seized every opportunity to 
organize and prepare people for his cause and was the first intellectual who discovered the important role of mosques and recommended members of the league of humanity to gather in mosques whenever they could, especially on Fridays. He expounded the meaning of humanity, the principles of progress and the necessity of unity against despotism, in such holy places. In this period of activity, Malkom Khan founded "the league of humanity" with almost similar structure to that of a political party to attract and train elements from different classes of people to participate in the political struggle. From this viewpoint, the league was a suitable organization for the political modernization program from bottom-up. This was in contrast to his approach in the first period when he founded the Faramoosh Khaneh, during which time the approach was for political modernization from above.

\section{Nation-Building}

Nation building is cultural aspect of political modernization. According to Almond \& Powell (1966) "nation-building emphasizes the cultural aspects of political modernization. It refers to the process whereby people transfer their commitment and loyalty from smaller tribes, villages, or petty principalities to the larger central political system in a nation-state" (p. 36). In the case of Malkom Khan, nation building implied both citizens and nation in its modern concept instead of its old and traditional meaning which will be discussed fully in the following part.

\subsection{Concept of Nation as Raiyyat and Ommat}

In the Qajar era there was no institutions or efficient organizations in civil society and grand ayatollahs were the chiefs of the nation, and the king, chancellor and ministers were the chiefs of state. The concept of nation in terms of the sharia was sometimes religion and sometimes referred to the followers of sharia or religion and the concept of government or state meant kingdom, governance or agents of the government (Ajoodani, 2009). The judicial system, record of lands and properties, contracts and litigation were the domain of the chiefs of nation, the clergymen and political governance was for the government. If such a structure of political and social power division were not viewed in the correct perspective, it would be difficult to understand the thoughts of Malkom Khan and his concept of nation-state.

Shahrestani, one of the significant religious men of Shiite divided the people of the world into several nations in his book, melal-va-nahl. In this division, when he named Iranians in the context of religion and nation, he named them as Majous; and when he speaks about Iranians in terms of race, language etc., he named them as Ajam (non-Arabs). Therefore, in dividing the people of the world into Arab, Persian, Roman and Indian categories, it appears to be based more on cultural factors like language, rather than religion. Such a concept of nation is close to that of the Islamic concept (Shahrestani, 1997). In the past the concept of nation was the same as the concept of ommat and there was no difference between these two. It means that ommat referred to the people when their religion was considered, thus there would be the Christian nation, Zoroastrian nation, Jewish nation etc.

This concept of nation and its intricate and intimate association with religion and followers of the religion, along with the concept of kingdom and power of governance is a notable concept 
in the history of the Islamic periods. Such a concept was the dominant concept stemming from the two words of 'nation' and 'state', since the emergence of thoughts on rule of law and constitutionalism (Ajdani, 2007). The use of state to mean kingdom in historical texts and Persian literature and poems of Iran has a long history. 'nation' and 'state' or in more commonly known terms, 'religion' and 'kingdom' were based on the basic principle of political and social power in the history of Iran in the Islamic periods and particularly in Qajar history. The differentiation between these two was for the purpose of separating political power from social power.

Another point is the word raiyyat ("peasant") which means people and nation. Mirzaye Shirazi wrote in one of his letters to Naser al-din Shah in regard to the issue of privileges involving tobacco that "you do the work that creates happiness and joy and hope for the nation (roayaa) or peasants and this work has no negative impact on the rules of nation and independence of the government (Broojerdi, 2003). The important point is that in the writings of Mirza Shirazi and other clergymen, when speaking about peasants, it means all people who are politically dependent on the government. This is the concept that was attached to the word "nation". In other words, the concept of nation means raiyyat (peasant) who are the followers of the government and are dependent on clergymen as the nation (followers of religion). Both concepts (peasant and ommat) differ from the modern political concept of establishing a legal political relationship between state and nation (in modern meaning) which is constituted through mutual rights and obligations between these two groups and human rights based on civil rights and the right to determine one's own fate.

\subsection{Introducing the Concept of Nation as a Modern Concept}

It was discovered that Malkom Khan had established his own program in modernization from above that was tantamount to lawlessness and replaced this kind of government with hokoomate motlagheye montazem or (absolute monarchy with law as the basis and method of its operation); this translates as a centralized government based on law. But he had another approach for establishing a nation-state during the second period of his reform activity when he advocated national solidarity based on the rights and freedoms of people, public interest and the constitution of government. He became the harbinger of national solidarity in Iran and he pushed for the establishment of a nation-state by putting priority on the establishment of nation or nation building.

He pointed out at this time that the survival of a government should be dependent on the life of a nation. When the nation is not 'alive' (meaning it is in an abject state), the government also should cease to exist. This type of government destroys a nation and it will be destroyed itself. If Iranians wanted a credible government, they should first revive the nation (Malkom Khan, 1976h). He believed that it was through awakening of the nation that the government could change. He believed that: the history of the world had amply demonstrated that to awaken the government, the nation had first to be awakened. It was time to stop asking and begging from the king and government officials; it was now time to demand that the nation should act (Malkom Khan, 1976j). Malkom Khan used the effective platform of the Ghanoon newspaper to propagate the idea of national solidarity. In his attempt to awaken the nation to 
the need for nation-building he considered various aspects of Iranian backwardness. He disagreed with every element of traditional society that was in conflict with the concept of nation building and he gave new interpretations from many traditional beliefs to call for the preservation of rights and the freedom of the people and giving priority to public interest and constitutional government on the basis of marame adamiyyat (principle of humanity). He was one of the first thinkers to give attention to the problem of women and their social participation, whilst defending their rights. In the seventh issue of the Ghanoon newspaper, he wrote:

Half of each nation comprises women. No national plan is done without help and cooperation of women. Iran's women should be the propagators of the humanistic aim. Their existence should be respected in every place. A woman, who is Adam, (human) can be a significant resource for progress of humanity"(Adamiyyat) (Malkom Khan, 1976f). A very important point to note is that Malkom Khan realized that the appropriate approach toward nation building should be through planned objection and challenge rather than through chaotic rebellion. It is not possible for Iranians to become rebels. The people of this land at different times were rebels and had continuously changed their kings only to face the same kind of situation after each change. We (Adamiyan) want to remove the custom of rebellion and bloodshed from the history of Iran (Malkom Khan, 1976i). The establishment and progress of the government institution requires that there be objection by the nation and MalKom Khan believed that progress of the government has been by objection, not by silence.

In his opinion, Iranians should either die or should have right of life and citizenship. MalKom Khan wrote in a very conscious reaction against the tobacco movement that: "destruction of nations is because of their silence, not their enthusiasm. This (tobacco) movement by the nation was more useful than a hundred ministers for Iran. "Enemies and friends understood that in addition to these useless and wicked ministers, there was a nation, and I, as a very small member of this nation, inform you from the soul of this nation that we are tired of the way the kingdom has been governed and we have decided to have a government - and we will have it" (Malkom Khan, 1976h).

He emphasized the element of challenge and struggle as being necessary for the continuity of nations and the tobacco movement signified the resurgence and rise of a nation. This demonstration of modernization from the bottom had far more impact than modernization from above. Malkom Khan then analyzed the tobacco movement from a political viewpoint. $\mathrm{He}$ explained the purpose of establishing majlise shoraye melli (national consultative assembly) based on this and said: Iranians want to arrange a majlise shoraye melli (national consultative assembly) in Iran by which the assembly of great religious men and wise people of the country safeguard the rights of the nation and the state on the basis of the religion of Islam (Malkom Khan, 1976g). It should be pointed out that if the establishment of a nation-state in the West is accompanied by the increased importance of the individual against the society (for example in English liberalism), Malkom placed greater emphasis on individual rights and freedom, based in this case, on his political programs for modernization. It was a case that was significant in the political thought of Iran. Against the backdrop of a despotic government, whereby all people are equal. In the eyes of the despotic government, 
the individual has no worth as such. The individual is a peasant (rayyiat) who draws his identity from the despotic ruler. In the religious thought of Iranians after Islam, it was not the individual, but the ommat that was the priority in the consideration of a nation.Malkom Khan was one of the first thinkers in Iran who considered the individual as a citizen in relation to society and considered him an individual with a social identity and ceaselessly defended their rights and individual freedom. He considered the individual and the social aspect of the human together, and referring to one of the outcomes of a law-based government he wrote:

In a country where law exists, all people increase their government's order and grandeur day by day, either because of their own interests or because of the public interest (Malkom Khan, 1976g).

With the challenge of the people against the Qajars beginning to mount, he attempted more to make people aware of their political and social rights. "Insans without rights of Adamiyyat (humanity) are like captured animals and as much as they try in this world, they do not earn anything except pain and adversity" (Malkom Khan, 1976o).

\section{Reconciling of Modern Political Ideas with Islamic Beliefs and Values}

It was in the period of publishing the Ghanoon newspaper that Malkom regarded people's traditional and specifically religious culture closer than in the previous period. He understood that it was inevitable to pay attention to this traditional and religious culture for the purpose of advancing his thoughts in Iran's society. It is important to consider that in such a situation, no political idea and activity with the aim of changing the status-quo and wrapped within the framework of a modernization program from bottom could succeed in practice, unless it could claim that there was compatibility, or at least that there was no incompatibility, between predominant Islamic rules and Western modern concepts or thoughts of modernization. In this part, the researcher will consider how Malkom Khan attempted to do this task and how he connected his political thoughts which originated from the West, with the predominant perception of Islamic rules and beliefs at that time in society. It would be a good idea at this juncture, to discuss the personal beliefs of Malkom Khan on religion. Malkom was a secular intellectual and did not follow any particular religion. But at the same time, he knew that religion, especially in Asian countries, still had a specific social role. Both these aspects of his personal attitude towards religion have been reflected in the report of his discussion with Mirza Fathali Akhoondzadeh. As he wrote to Akhoond Zadeh:

"Every religion consists of three elements: beliefs, rites and ethics. The main purpose of religion is constituted by the third element. Beliefs and rites serve only to reinforce and provide sanction for a moral code. In Asia, the sciences are not yet widespread, and it is therefore necessary to maintain these two elements in order to secure the morality, which is the fundamental aim of every religion (Akhund zadeh, 1963). Therefore, it should be said that Malkom Khan had not even an eclectic attitude on religion. All of his political thought and behavior show that he was a thinker with a materialistic ideology, with emphasis on ethics and the well-being of man. Meanwhile, the nature of his personal behavior with regard towards religious beliefs can be shown by a specific example. It is this personal behavior which reveals an appropriate reflection of his political-social attitude toward religion. Mirza 
Hosein Khan Moshir al-Dowleh (the next Sepah Salar) was influenced by Malkom's thoughts during the period of Malkom's exile to Istanbul and subsequently prepared the grounds for his return to bureaucracy. At this time although Malkom Khan held the policy of unity with clergymen during this period, but he soundly criticized them both from general and specific aspects. For example, his general criticism appeared in the book of "inshaallah, Mashaallah" in which he wrote:

European countries did not reach this degree of development until they became free from their Pope's domination. When they were overwhelmed by superstitions and imitating their clergymen, their situation was much worse than that of Iranians. There is great likelihood that anyone who spoke in this manner would be imprisoned and executed immediately without inquiry by these clergymen at that time (Adamiyyat, 2009). At other times, Malkom Khan implicitly criticized the conservative class of clergymen in order to encourage them to support his modernization thoughts and also to drive a wedge between them and the government. In order to explore Malkom Khan's approach to religious culture more profoundly in this period, first of all his attitude toward Islam must be discussed, followed by his tactic of linking Islamic principles and his political thought which originated from Western political thought.

Shortly after his dismissal from his ambassadorship position, Malkom Khan, in a speech in London in 1891, delivered in the presence of English priests, stated that:

"I assure you that this little development achieved in Iran and Ottoman, especially in Iran, is the result of this fact - that those who received Western beliefs and principles said that: 'Western countries are not important for us. These thoughts and beliefs have originated from Islam and Europeans have taken them from us (Muslims), instead of saying that the origin of those beliefs is from Europe or those principles are from England, France or Germany. This method has had a wonderful effect" (Asil, 2002e, p. 164).

This lecture on Iranian civilization shows Malkom Khan's instrumental tactic in propagating his political program; it also appeared in the Ghanoon newspaper and his other writings. This research will now evaluate Malkom Khan's attitude and strategies. It was clear that in many aspects, Western culture and principles of civilization were not in tandem with Islam, but in order to prevent Muslims especially Shiites from rejecting these principles, it was necessary to say that all of these principles originated from Islam and that the Western people had taken them from Muslims (Asil, 2002e). Malkom Khan explains why he had adopted such an attitude, and that was because he believed that Muslims recognize only the authority - that of the religion of Islam. He pointed out that Islam was not like Christianity which separates mundane life from spiritual life. By having this perceptive understanding of the dominant interpretation of Islam at that time, Malkom Khan concluded that as Muslims believe that: Islam is a comprehensive faith which consists of all the sciences, so they would not be willing to accept any knowledge and science from followers of other religions. If Western culture and civilization principles were offered to Muslims as from non-Islamic sources, they would be rejected outright (Goodarzi, 2008). In the Ghanoon newspaper, in a discussion about the necessity of compiling a constitution which he named the "Great Law", he wrote: 
"Supporters of Iran's government must help each other to establish this Great Law, which in all countries, is the source of prosperity. Implementing this wish does not have any problem for Iranians because of two reasons. First, the principles of this law are correspondent with the principles of Islam just as other governments have taken their great laws from Islamic principles. Second, establishing of this law has been facilitated by foreigners that Iranians can also accept it without any problem, the way they have adopted other modern developments and establish them in Iran in accordance with the principles of Islam" (Malkom Khan, 1976). About 15 years after Malkom Khan's writings about the great law, the Iranian Constitution was written according to the political-social climate of that time as Malkom Khan had suggested. His first goal was compiling of the Constitution in the course of political modernization, which did not have any precedence in the history of Iranian's political thought. According to Malkom Khan, Iranians should adopt the constitution from developed countries and compile and implement it in a way compatible with the principles of Islam. Even in this case it can be observed how he first talked about implementing the rules of divine justice and then immediately he posed the subject of compiling and legislating which was the responsibility of parliament. So, the first step of his strategy was to prevent readers from rejecting his idea by invoking universal themes which could not be denied, and then presenting his ideas of modernization so that it would be congruent with that universal truth.

It is necessary to explain that this attitude had a special aspect too, which was his claim about the complete compatibility of all his political opinions with Islamic rules and beliefs. Repeatedly, he made it very clear that none of his political opinions and goals were in discord with Islamic tenets and beliefs. For example, he correctly conceived legal security as the necessity of Aghde Jema'at. He pointed out that: this type of security, which was earlier thought impossible, had been well-established in other countries for centuries. This type of legal security was the same security which Islam made obligatory for Muslims in their gatherings, and thus there was no justification for any law which did not strengthen legal security (Malkom Khan, 1976k). Previously, it has been discussed that Malkom Khan in order to fight the Qajars attempted to unite people on the basis of his political goals. Yet, he attributed this decree (fighting oppression) to Islam and said:

The wisdom of arranging a congregation is one of the principles of Islam - and perhaps a miracle of this religion. There is no action in Islam which is not based on law. Jihad or fighting with enemies of Islam has special laws. Group prayer (namaz e-jima'at) is based on union. Islamic conquests were all the result of sound wisdom. It can even be proved that all rights of humanity (Adamiyyat) that foreign countries had gained by the power of congregation were the result of wise laws adopted from Islamic principles. In this era, all philosophers believed that fighting against oppression was never possible except by solidarity and unity (Asil, 2002a). In evaluating the correctness of this attitude of Malkom Khan, it should be determined if his opinion was true regarding Muslims' greater attention to the issues that they believed were Islam-oriented. Historical evidence shows that his opinion was indeed true. Traditional and conservative clergy's intensive propaganda against political reform and intellectuals was based on the view that thoughts related to political reform and constitutionalism belonged to infidel foreigners and modernist intellectuals, and these action 
sufficiently demonstrate that they were just a group of irreligious miscreants.

\section{Conclusion}

Malkom khan in line with political modernization from bottom proposed parliamentary constitutional monarchy as most proper type of government for Iran and for this purpose published ghanoon news sheet to propose his idea. he proposed a parliament in the name of national consultative assembly to have representatives elected by the people. For the first time, he spoke about the necessity of three organs of power in the structure of government and also the separation of powers, which indicated a major shift in his political thought. He intended for the limiting the absolute power of the monarch and putting power within the framework of law and emphasized the people's surveillance over political power. In fact, the ghanoon clearly expressed way Malkom's political goal, which was how to change the absolutist government to a parliamentary constitutional monarchy. Malkom being aware that such a change needed a political organization established the League of Humanity (majmae-adamiyyat) and introduced the ideology of Adamiyyat (maramead amiyyat) as its ideology. In this period of activity, Malkom Khan founded the League of Humanity almost with similar structure to that of a political party to attract and train elements from different classes of people to participate in the political struggle. From this viewpoint, the League of Humanity (majmae adamiyyat) was a suitable organization for the political modernization program from the bottom-up. Malkom Khan in the first period of his reform equated the despotic government with statelessness and set his main goal as replacement of this kind of government with sultanate motlaghey e- montazem or absolute monarchy, based on law and his main aim was the creation of differentiated and specialized political structures. In other words, his thinking was in line with state-building. But in the second period he took the different approach of nation-state. The concept of nation had been applied as a traditional and non-modern concept as peasant (raiyyat) and ommat (followers of shariah) but Malkom applied the concept of nation in its modern sense and attempted nation building.

Malkom Khan in the second period of his political thought and activity realized the important role of religion and religious culture of the people and found it imperative to take into due consideration the religious culture of the people in order to promote his thoughts. He fully acknowledged the powerful forces of religion and the clergy, and concluded that no modernization plan from bottom would be successful unless he could reconcile modern and Western thoughts with Islamic beliefs and thoughts. Therefore he attempted in his writings to bring evidence from the hadith and Quran to achieve this reconciliation. This was to prevent possible opposition from the clergy and conservative segment of the populace to his thoughts and also in order to attract the support of the progressive class of clergymen with his political modernization thoughts, which were developed on the basis of parliamentary constitutional monarchy

\section{References}

Adamiyyat, F. (2009). Fekre Azadi va Moghadame ye Nehzate Mashrootiat. Tehran: Kharazmi. 
Ajdani, L. (2007). Roshanfekrane Iran Dar Asre Mashrooteh Tehran: Akhtaran.

Ajoodani, M. (2009). Mashrootey e-Irani. Tehran: Akhtaran.

Akhund zadeh, F. (1963). Alefbaye Jadid Va Maktubat: Farhangestane Oloome Jomhooriye Shoravi ye Sosialistiye Azarbayjan.

Algar, H. (1973). Mirza Malkum Khan: A Biographical Study to Iranian Modernism: Uc Press.

Almond, G., \& Powell, G. B. (1966). Comparative Politics: A Developmental Approach: Boston Little Brown and Co.

Asil, H. (2002a). Resaleha ye Malkom Khan. Resale ye-Tofighe Amanat. Collected Works. Tehran: Ney.

Asil, H. (Ed.). (2002b). Resaleha ye- Malkom Khan. Resaleye Osule Mazhabe Divanian (Collected Works. Tehran: Ney.

Asil, H. (Ed.). (2002c). Resaleha ye -Malkom Khan. Resale ye Inshaallah and Mashaallah. (Collected Works. Tehran: Ney

Asil, H. (Ed.). (2002d). Resaleha ye Malkom Khan Nazem al -Dowleh. Resaleye Tofighe Amanat (Collected Works. Tehran.

Asil, H. (Ed.). (2002e). Resaleha ye Malkom Khan. Resaley e -Madaniyyate Irani (Collected Works. Tehran: Ney.

Asil, H. (Ed.). (2002f). Resalehaye Malkom Khan. Resaleh ye Osoole damiyyat. Collected Works. Tehran: Ney.

Broojerdi, M. (2003). Roshanfekrane Iran Va Gharb Tehran: Farzan.

Goodarzi, G. (2008). Mazhab Va Roshanfekrane Mashrooteh Tehran: Akhtaran.

Haghani, M. (2002). Tarikhe Tahavollate Siasi Iran. Tehran: Moasseseye Motaleate Tarikhe Moaser e Iran.

Jamshidi, M. H. (1999). Malkom khan :Roshanfekre Gharbzadeh Nameh Pazhoohesh(7).

Malkom Khan, M. (1976a). Ghanoon Newspaper (No 5) Collected Works. (H. Nateq Ed.). Tehran.

Malkom Khan, M. (1976b). Rooznameh ye Ghanoon.(No 24). Collected Works (H. Nateq Ed.). Tehran.

Malkom Khan, M. (1976c). Rouzname ye-Ghanoon (No 6). Collected Works. (H. Nateq Ed.). Tehran.

Malkom Khan, M. (1976d). Rouzname ye -Ghanoon (No 2). Collected works (H. Nateq Ed.). Tehran.

Malkom Khan, M. (1976e). Rouznameh ye-Ghanoon (No 1).Collected works. (H. Nateq Ed.). 
Tehran.

Malkom Khan, M. (1976f). Rouznameh ye-Ghanoon (No 7) Collected Works (H. Nateq Ed.). Tehran.

Malkom Khan, M. (1976g). Rouznameh ye-Ghanoon (No 11) Collected Works (H. Nateq Ed.). Tehran: Amir Kabir.

Malkom Khan, M. (1976h). Rouznameh ye-Ghanoon (No 22) Collected Works (H. Nateq Ed.).

Malkom Khan, M. (1976i). Rouznameh ye-Ghanoon (No 22) Collected Works (H. Nateq Ed.).

Malkom Khan, M. (1976j). Rouznameh ye-Ghanoon (No 23) Collected Works (H. Nateq Ed.). Tehran: Amir Kabir

Malkom Khan, M. (1976k). Rouznameh ye -Ghanoon (No 13) Collected Works (H. Nateq Ed.). Tehran: Amir Kabir

Malkom Khan, M. (19761). Rouznameh ye -Ghanoon (No 30) Collected Works (H. Nateq Ed.). Tehran. Amir Kabir

Malkom Khan, M. (1976m). Rouznameh ye Ghanoon (No 4) Collected Works (H. Nateq Ed.). Tehran. Amir Kabir

Malkom Khan, M. (1976n). Rouznameh ye Ghanoon (No 23) Collected Works (H. Nateq Ed.). Tehran. Amir Kabir

Malkom Khan, M. (1976o). Rouznameh ye Ghanoon (No 27) Collected Works (H. Nateq Ed.).

Malkom Khan, M. (1976p). Rouznameh ye Ghanoon. (No19) Collected Works (H. Nateq Ed.). Tehran. Amir Kabir

Malkom Khan, M. (1976q). Rouznameh ye Ghanoon. (No 18) Collected Works (H. Nateq Ed.). Tehran: Amir Kabir

Raoofi, S. (2007). Bonyanha ye Fekriye Enghlabe Mashrooteh. Tehran: Agah.

Shahrestani, M. (1997). Tozih al Melal (M. Khaleghdad Hashemi, Trans.). Tehran: Eghbal.

Zibakalam, S. (2006). Sonnat va Moderniteh Tehran: Roozaneh.

\section{Copyright Disclaimer}

Copyright for this article is retained by the author(s), with first publication rights granted to the journal.

This is an open-access article distributed under the terms and conditions of the Creative Commons Attribution license (http://creativecommons.org/licenses/by/3.0/). 